\title{
ENDEMIC HEPATITIS E IN TWO NORDIC COUNTRIES
}

\author{
H Norder (helene.norder@smi.se) ${ }^{1}$, L Sundqvist ${ }^{1}$, L Magnusson ${ }^{1}$, S Østergaard Breum², M Löfdahl ${ }^{3}$, L E Larsen², C K Hjulsager², \\ L Magnius ${ }^{1}$,B E Böttiger ${ }^{4}$, F Widén ${ }^{5}$ \\ 1. Department of Virology, Swedish Institute for Infectious Disease Control (Smittskyddsinstitutet, SMI), Solna, Sweden \\ 2. Department of Veterinary Diagnostics and Research, National Veterinary Institute, Technical University of Denmark (DTU), \\ Copenhagen, Denmark \\ 3. Department of Epidemiology, Swedish Institute for Infectious Disease Control (Smittskyddsinstitutet, SMI), Solna, Sweden \\ 4. Department of Virology, Statens Serum Institut, Copenhagen, Denmark \\ 5. Department of Biomedical Sciences and Veterinary Public Health, Swedish University of Agricultural Sciences, \\ Uppsala, Sweden
}

Antibodies against hepatitis E virus (anti-HEV) were found in 248 Swedish and Danish patients between 1993 and 2007. Most patients were symptomatic and tested for anti-HEV due to travel abroad. Among patients with known country of infection, most were infected in Asia, mainly on the Indian subcontinent. However, 29 patients were infected in Europe, nine of these had HEV IgM and/or HEV RNA in serum. In sera from 65 of 141 tested patients HEV RNA could be detected, and 63 strains could be typed by limited sequencing within ORF2. HEV RNA was found in sera from $71 \%$ of the patients with HEV IgM and IgG and in $18 \%$ of the patients with only detectable HEV IgG. It was also found up to three weeks after the onset of disease in $67 \%$ of the patients with known date of onset. Patients infected in Europe were infected by genotype 3 , and were older than those infected by genotype 1 (mean age 55.3 vs 30 years, $p<0.001$ ). Since it is known that genotype 3 can infect domestic pigs, HEV strains from 18 piglets in 17 herds in Sweden and Denmark were sequenced. Phylogenetic analyses of the genotype 3 strains showed geographical clades and high similarity between strains from patients and pigs from the same area. There are thus autochthonous hepatitis E cases in Scandinavia, and there are probably many undiagnosed ones. Patients with hepatitis of unknown etiology should therefore be investigated for anti-HEV even if they have not been outside Europe, since infections acquired from pigs or other animals should be taken into consideration.

\section{Introduction}

Hepatitis E virus (HEV) is a non-enveloped positive-stranded RNA virus of 27-34 nm in diameter [1]. It is the only member of the genus Hepevirus in the family Hepeviridae. The genome is approximately $7.2 \mathrm{~kb}$ in length and encodes three open reading frames, from ORF1 to ORF3. ORF1 encodes for enzymes important for replication and transcription, ORF2 encodes for a capsid protein and ORF3 for a small protein of 122 or 123 amino acids that interacts with cellular proteins and contributes to viral replication. There is only one serotype but based on genetic diversity HEV strains are classified into four genotypes designated with Arabic numerals 1 to 4 . The genotypes are further divided into up to seven subtypes designated with Roman characters $a-g$, each with distinct geographical distribution [2]. Genotypes 1 and 2 only infect humans, mainly in Asia, and Africa, where they are endemic and may cause large outbreaks. Genotype 2 has been found causing outbreaks in Mexico and Africa. Strains of the other two genotypes, 3 and 4 , have been shown to infect not only humans, but also domestic pigs, wild boars, deer, and other mammals. These two genotypes have not been reported to cause outbreaks. In endemic countries, as India, genotype 1 infects humans, while HEV isolates from swine belong to genotype 3 or 4 [3]. However, genotype 3 strains have also been isolated from sporadic human cases of hepatitis $\mathrm{E}$, and from domesticated pigs in several European countries, in the United States (US) and in Japan, while genotype 4 strains have been found in humans and pigs exclusively in Asia, as China, Taiwan, Japan and Vietnam [4-7].

Hepatitis $\mathrm{E}$ is transmitted mainly by the faecal-oral route, usually through contaminated drinking water. Usually, the infection is self-limited, although some persons develop fulminant hepatitis. In pregnant females the illness is particularly severe with up to $20 \%$ fatality rate in the third trimester, but it may be even higher in patients with underlying chronic liver disease [8,9]. Chronic hepatitis $\mathrm{E}$ infections have also been described in transplant patients on immunosuppressive treatment [10].

Hepatitis E was previously considered to mainly affect the inhabitants of or travellers to Asia and Africa, due to high endemicity in these parts of the world. However, in recent years there have been several reports on autochtonous hepatitis $E$ cases in Europe, including United Kingdom (UK), the Netherlands and France $[6,7,11,12]$, and also in the US, New Zealand and Japan $[4,13,14]$. There have also been increasing numbers of reports on high seroprevalence in Europe and the US. Antibodies againts HEV (anti-HEV) were found in 17\% of blood donors in the UK and in France, in $21-33 \%$ of blood donors and $50 \%$ of farmers in Denmark and 5 to $9 \%$ of the general population and $13 \%$ of veterinarians in Sweden [11,15-18]. These data indicate that there is a high prevalence of hepatitis $E$ infections also in Europe, albeit most infections are subclinical and most of them may be zoonotic. The study presented here was performed to investigate which genotypes of HEV were imported to Denmark and Sweden between 1993 and 2007, and to find out if there were any endemic HEV strains and, 
if so, to determine their relation to HEV strains obtained from pigs in these countries.

\section{Materials and methods}

\section{Identification of human cases with hepatitis $\mathbf{E}$}

Patients with a recent travel history and with clinical signs of hepatitis not caused by hepatitis A, B, C or D virus were investigated for hepatitis $E$ at the Swedish Institute for Infectious Disease Control (Smittskyddsinstitutet, SMI), Solna, Sweden. Sera from these patients were tested for HEV IgG and IgM by a kit using two recombinant $\mathrm{HEV}$ antigens corresponding to structural region of the HEV (Diagnostic Biotechnology, Singapore). Between 1993 and 2006, all samples were also tested for HEV IgG and IgM by using the until then commercially available ELISA kits from Abbott Laboratories (Abbott Laboratories, Chicago, IL). All reactive sera were tested for HEV RNA by PCR and the amplified fragments were sequenced.

\section{Identification of pigs infected by HEV}

HEV RNA was isolated and sequenced from $18 \mathrm{HEV}$ strains from pigs. The strains were obtained from two HEV prevalence studies (Breum, unpublished; Widén et al., unpublished). Eight strains were from piglets from seven Danish pig herds and 10 strains were from piglets from 10 Swedish herds.

\section{RNA extraction}

HEV RNA was extracted from 200 ul serum from humans or faecal suspension from pigs using QIAamp UltraSense Virus Kit (Qiagen, $\mathrm{GmbH}$, Germany) as described by the manufacturer. Five ul RNA were used for cDNA synthesis in $20 \mathrm{ul}$ mix containing 5 ul 5X First Strand buffer (Invitrogen, Life Technologies, Carlsbad,
CA), 10 mM DTT (Invitrogen, Life Technologies, Carlsbad, CA), 0.5 mM dNTP (Thermo Scientific, Abgene $®$, Epsom, UK), $100 \mathrm{U}$ Superscript II Reverse Transcriptase (Invitrogen, Life Technologies, Carlsbad, CA), 0.5 ul RNasin (Promega, Madison, US) and $0.1 \mathrm{U}$ random hexamere primers (Roche Diagnostics, GmbH, Germany). Reverse transcription was performed at room temperature for 15 minutes and then at $42^{\circ} \mathrm{C}$ for two hours.

\section{Nested PCR in the RdRp domain of ORF1 region}

A nested PCR was carried out in a 50 ul reaction with $5 \mathrm{ul} \mathrm{cDNA}$, $0.06 \mathrm{ul}$ of $0.2 \mathrm{mM}$ of each primers ISP-4232 and EAP-4576 [19], 5 ul 10X Taq.buffer general, 2 mM MgCl2 (Applied Biosystems, Roche Molecular Systems, New Jersey, US), 0.2 mM dNTP (Thermo Scientific, Abgene ${ }^{\circledR}$, Epsom, UK) and 4 U Taq polymerase (Thermo Scientific, Abgene $\AA$, Epsom, UK). The PCR reaction was carried out for 40 cycles with denaturation at $94^{\circ} \mathrm{C}$ for $20 \mathrm{~s}$, annealing at $60^{\circ} \mathrm{C}$ for $30 \mathrm{~s}$ and extension at $72^{\circ} \mathrm{C}$ for $60 \mathrm{~s}$. The second round reaction was carried out similarly but with $5 \mathrm{ul}$ first round product instead of cDNA, $2.5 \mathrm{mM} \mathrm{MgCl}$ and $0.06 \mathrm{ul}$ of $0.2 \mathrm{mM}$ of each primer ISP-4232 and IAP-4561 [19].

\section{Nested PCR in the ORF2 region}

Two different nested PCRs for amplification of the ORF2 region were performed. PCR: 1 was carried out in a $50 \mathrm{ul}$ reaction with 10 ul cDNA, 0.1 ul of $0.2 \mathrm{mM}$ primer HE110 [14], 0.119 ul of 0.2 mM primer HE041 (14), 5 ul 10X Taq.buffer general, 2.5 mM $\mathrm{MgCl} 2,0.2 \mathrm{mM}$ dNTP, $6 \mathrm{U}$ Taq polymerase. The PCR reaction was carried out for 40 cycles of denaturation at $94^{\circ} \mathrm{C}$ for 20 s, annealing at $56^{\circ} \mathrm{C}$ for $20 \mathrm{~s}$ and extension at $72^{\circ} \mathrm{C}$ for $60 \mathrm{~s}$. The second round reaction was carried out with 5 ul PCR product, primers HE110 and HE3159 [20] with reagents and cycling as in the first round.

T A B L E 1

Age and sex distribution of patients from Sweden and Denmark (1993-2007) with serological markers against hepatitis E virus (HEV)

\begin{tabular}{|c|c|c|c|c|c|c|c|c|c|c|c|}
\hline \multirow[b]{3}{*}{ Age } & \multicolumn{5}{|c|}{ Number of patients with anti-HEV IgM } & \multicolumn{5}{|c|}{ Number of patients with anti-HEV IgG only } & \multirow[b]{3}{*}{ Total } \\
\hline & \multicolumn{2}{|c|}{ Sweden } & \multicolumn{2}{|c|}{ Denmark } & \multirow[b]{2}{*}{ Sub-total } & \multicolumn{2}{|c|}{ Sweden } & \multicolumn{2}{|c|}{ Denmark } & \multirow[b]{2}{*}{ Sub-total } & \\
\hline & M & $\mathrm{F}$ & M & $\mathrm{F}$ & & M & $\mathbf{F}$ & M & $\mathrm{F}$ & & \\
\hline $0-9$ & 0 & 0 & 2 & 0 & 2 & 0 & 1 & 2 & 0 & 3 & 5 \\
\hline $10-19$ & 8 & 1 & 3 & 1 & 13 & 2 & 2 & 3 & 0 & 7 & 20 \\
\hline $20-29$ & 13 & 8 & 8 & 6 & 35 & 8 & 4 & 9 & 2 & 23 & 58 \\
\hline $30-39$ & 4 & 4 & 6 & 2 & 16 & 7 & 3 & 24 & 7 & 41 & 57 \\
\hline $40-49$ & 4 & 0 & 2 & 1 & 7 & 9 & 4 & 14 & 3 & 30 & 37 \\
\hline $50-59$ & 0 & 1 & 1 & 1 & 3 & 5 & 5 & 11 & 10 & 31 & 34 \\
\hline $60-69$ & 2 & 3 & 3 & 0 & 8 & 2 & 5 & 9 & 2 & 18 & 26 \\
\hline$>70$ & 1 & 0 & 0 & 0 & 1 & 3 & 3 & 1 & 3 & 10 & 11 \\
\hline Total & 32 & 17 & 25 & 11 & 85 & 36 & 27 & 73 & 27 & 163 & 248 \\
\hline
\end{tabular}

$M=$ male, $F=$ female

T A B L E 2

Hepatitis E virus (HEV) RNA detection in serum samples from Swedish and Danish patients (1993-2007) with anti-HEV IgM and IgG or anti-HEV IgG only

\begin{tabular}{|c|c|c|c|c|c|c|c|}
\hline $\begin{array}{l}\text { Patient } \\
\text { origin }\end{array}$ & N & $\begin{array}{l}\text { Anti-HEV } \\
\text { IgM + IgG }\end{array}$ & $\begin{array}{l}\text { Anti-HEV } \\
\text { IgG only }\end{array}$ & HEV RNA positive (\%) & $\begin{array}{l}\text { HEV RNA in IgM + IgG } \\
\text { positive sera }\end{array}$ & $\begin{array}{l}\text { HEV RNA in IgG only } \\
\text { positive sera }\end{array}$ & $\begin{array}{c}\text { Number of } \\
\text { sequenced strains }\end{array}$ \\
\hline Sweden & 82 & 44 & 38 & $44(57 \%)$ & $38(86 \%)$ & $9(24 \%)$ & 44 \\
\hline Denmark & 59 & 36 & 23 & $21(36 \%)$ & $19(53 \%)$ & $2(9 \%)$ & 21 \\
\hline Total & 141 & $80(57 \%)$ & $61(43 \%)$ & $65(46 \%)$ & $57(71 \%)$ & $11(18 \%)$ & $63(97 \%)$ \\
\hline
\end{tabular}


T A B L E 3

Presence of hepatitis E virus (HEV) RNA in serum of patients from Swedish and Denish patients (1993-2007) in relation to onset of disease when this information was known

\begin{tabular}{|l|c|c|c|}
\hline $\begin{array}{l}\text { Number of } \\
\text { weeks after } \\
\text { onset of } \\
\text { disease }\end{array}$ & $\begin{array}{c}\text { Number of } \\
\text { samples }\end{array}$ & $\begin{array}{c}\text { HEV RNA detection } \\
\text { in ORF 1/number } \\
\text { tested (\%) }\end{array}$ & $\begin{array}{c}\text { HEV RNA detection } \\
\text { in ORF 2/number } \\
\text { tested (\%) }\end{array}$ \\
\hline 1 & 53 & $35(66 \%)$ & $30(57 \%)$ \\
\hline 2 & 6 & $6(100 \%)$ & $3(50 \%)$ \\
\hline 3 & 3 & $2(67 \%)$ & $1(33 \%)$ \\
\hline 4 & 8 & $2(25 \%)$ & $3(38 \%)$ \\
\hline 5 & 4 & $2(50 \%)$ & $2(50 \%)$ \\
\hline$>6$ & 10 & $1(10 \%)$ & 0 \\
\hline Total & 84 & $48(57 \%)$ & $39(46 \%)$ \\
\hline
\end{tabular}

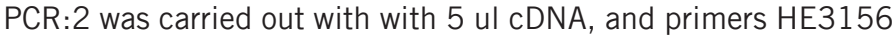
and HE3157 [20]. Two microliters of this product were further amplified with primers HE3158 and HE3159 [20].

\section{Sequencing the ORF2 region}

The amplified products were purified using the EZNA Cycle Pure Kit (Omega Bio-Tek, GA, US) according to the manufacturers instructions. The sequencing reaction was made with BigDye Terminator Cycle Sequencing Ready reaction kit version 3.1 (Applied Biosystem, CA, US). The ABI PRISM 3100 genetic analyser (Applied Biosystems, CA, US) was used for electrophoresis and data collection.

\section{Phylogenetic analysis}

The sequences obtained were analysed in the programs SeqMan and Sequencing Analysis. Eighty-four analysed sequences were aligned with the corresponding region of 554 sequences obtained from GeneBank. The phylogenetic analysis was carried out with the

T A B L E 4

Reported country of infection and infecting hepatitis E virus (HEV) genotype of Swedish and Danish patients (1993-2007) with anti-HEV IgM and IgG or with only detectable anti-HEV IgG

\begin{tabular}{|c|c|c|c|c|c|c|c|}
\hline $\begin{array}{l}\text { Country/region of } \\
\text { infection }\end{array}$ & $\begin{array}{l}\text { Number of } \\
\text { samples }\end{array}$ & $\begin{array}{l}\text { Number of } \\
\text { samples from } \\
\text { patients with } \\
\text { anti-HEV IgM }\end{array}$ & $\begin{array}{l}\text { Number of } \\
\text { samples from } \\
\text { patients with } \\
\text { anti-HEV IgG } \\
\text { only }\end{array}$ & $\begin{array}{c}\text { HEV RNA positive } \\
\text { samples/ tested from } \\
\text { patients with anti- } \\
\text { HEV IgM }\end{array}$ & $\begin{array}{l}\text { HEV RNA positive } \\
\text { samples/tested } \\
\text { from patients with } \\
\text { anti-HEV IgG only }\end{array}$ & Geno-type 1 & Geno-type 3 \\
\hline \multicolumn{8}{|l|}{ Europe } \\
\hline $\begin{array}{l}\text { Sweden } \\
\text { Sweden* } \\
\text { Denmark } \\
\text { Bulgaria } \\
\text { Canary Islands } \\
\text { Spain** } \\
\text { Italy } \\
\text { Majorca } \\
\text { Greece } \\
\text { Serbia } \\
\text { Poland } \\
\text { Russia } \\
\text { Subtotal }\end{array}$ & $\begin{array}{l}8 \\
1 \\
7 \\
1 \\
2 \\
2 \\
2 \\
1 \\
1 \\
2 \\
1 \\
1 \\
29\end{array}$ & $\begin{array}{l}1 \\
1 \\
2 \\
0 \\
0 \\
2 \\
0 \\
1 \\
0 \\
1 \\
0 \\
0 \\
8\end{array}$ & $\begin{array}{l}7 \\
0 \\
5 \\
1 \\
2 \\
0 \\
2 \\
0 \\
1 \\
1 \\
1 \\
1 \\
21\end{array}$ & $\begin{array}{c}1 / 1 \\
0 \\
2 / 2 \\
0 \\
0 \\
1 / 1 \\
0 \\
1 / 1 \\
0 \\
1 / 1 \\
0 \\
0 \\
6 / 6\end{array}$ & $\begin{array}{c}1 / 5 \\
1 / 1 \\
0 / 1 \\
0 / 1 \\
0 / 1 \\
0 \\
0 / 1 \\
0 \\
0 \\
0 \\
1 / 1 \\
0 \\
3 / 11\end{array}$ & $\begin{array}{l}0 \\
1 \\
0 \\
0 \\
0 \\
0 \\
0 \\
0 \\
0 \\
0 \\
0 \\
0 \\
1\end{array}$ & $\begin{array}{l}2 \\
0 \\
2 \\
0 \\
0 \\
1 \\
0 \\
1 \\
0 \\
1 \\
0 \\
0 \\
7\end{array}$ \\
\hline Asia & 2 & 1 & 1 & $0 / 1$ & $0 / 1$ & 0 & 0 \\
\hline $\begin{array}{l}\text { Afghanistan } \\
\text { Bangladesh } \\
\text { India } \\
\text { Nepal } \\
\text { Pakistan } \\
\text { Thailand } \\
\text { Singapore } \\
\text { Indonesia } \\
\text { Subtotal }\end{array}$ & $\begin{array}{c}5 \\
16 \\
34 \\
5 \\
15 \\
6 \\
1 \\
1 \\
85\end{array}$ & $\begin{array}{c}3 \\
12 \\
24 \\
4 \\
9 \\
0 \\
0 \\
0 \\
53\end{array}$ & $\begin{array}{c}2 \\
4 \\
10 \\
1 \\
6 \\
6 \\
1 \\
1 \\
32\end{array}$ & $\begin{array}{c}1 / 3 \\
8 / 11 \\
19 / 22 \\
4 / 4 \\
8 / 9 \\
0 / 0 \\
0 \\
0 \\
40 / 50\end{array}$ & $\begin{array}{c}0 / 2 \\
1 / 3 \\
4 / 9 \\
0 \\
2 / 3 \\
0 / 3 \\
0 \\
0 \\
7 / 21\end{array}$ & $\begin{array}{c}1 \\
9 \\
21 \\
4 \\
10 \\
0 \\
0 \\
0 \\
45\end{array}$ & $\begin{array}{l}0 \\
0 \\
0 \\
0 \\
0 \\
0 \\
0 \\
0 \\
0\end{array}$ \\
\hline \multicolumn{8}{|l|}{ Middle East } \\
\hline $\begin{array}{l}\text { Syria } \\
\text { Turkey } \\
\text { Iraq } \\
\text { Iran } \\
\text { Subtotal } \\
\end{array}$ & $\begin{array}{l}1 \\
1 \\
1 \\
1 \\
4\end{array}$ & $\begin{array}{l}0 \\
0 \\
1 \\
0 \\
1 \\
\end{array}$ & $\begin{array}{l}1 \\
1 \\
0 \\
1 \\
3\end{array}$ & $\begin{array}{c}0 \\
0 \\
0 / 1 \\
0 \\
0 / 1 \\
\end{array}$ & $\begin{array}{c}0 / 1 \\
0 / 1 \\
0 \\
0 \\
0 / 2 \\
\end{array}$ & $\begin{array}{l}0 \\
0 \\
0 \\
0 \\
0 \\
\end{array}$ & $\begin{array}{l}0 \\
0 \\
0 \\
0 \\
0 \\
\end{array}$ \\
\hline \multicolumn{8}{|l|}{ Africa } \\
\hline $\begin{array}{l}\text { Tanzania } \\
\text { Somalia } \\
\text { Ethiopia } \\
\text { Egypt } \\
\text { Subtotal }\end{array}$ & $\begin{array}{l}1 \\
1 \\
1 \\
1 \\
4\end{array}$ & $\begin{array}{l}0 \\
1 \\
0 \\
0 \\
1\end{array}$ & $\begin{array}{l}1 \\
0 \\
1 \\
1 \\
3\end{array}$ & $\begin{array}{c}0 \\
0 / 1 \\
0 \\
0 \\
0 / 1\end{array}$ & $\begin{array}{c}1 / 1 \\
0 \\
0 \\
0 \\
1 / 1\end{array}$ & $\begin{array}{l}1 \\
0 \\
0 \\
0 \\
1\end{array}$ & $\begin{array}{l}0 \\
0 \\
0 \\
0 \\
0\end{array}$ \\
\hline \multicolumn{8}{|l|}{ South America } \\
\hline $\begin{array}{l}\text { Dominican Republic } \\
\text { Brazil }\end{array}$ & $\begin{array}{l}2 \\
1 \\
\end{array}$ & $\begin{array}{l}1 \\
0\end{array}$ & $\begin{array}{l}1 \\
1\end{array}$ & $\begin{array}{l}0 \\
0\end{array}$ & $\begin{array}{c}0 / 1 \\
0\end{array}$ & $\begin{array}{l}0 \\
0\end{array}$ & $\begin{array}{l}0 \\
0\end{array}$ \\
\hline Country not reported & 122 & 21 & 101 & $8 / 22$ & $1 / 23$ & 9 & 0 \\
\hline Total & 248 & 85 & 163 & $54 / 80$ & $11 / 61$ & 56 & 7 \\
\hline
\end{tabular}

* Contact case to an infected relative from Pakistan

** The numbers for Spain exclude Canary Islands and Majorca which are listed separately 
PHYLIP package version 3.65 [21]. Evolutionary distances were using the F84 algorithm in the DNADIST program with transition/ transversion ratio of 4.29 . Phylogenetic trees were constructed using UPGMA and Neighbor-joining method in the NEIGHBOR program in the PHYLIP package. The trees were visualized using the program Tree View, version 1.6.6. Bootstrap analysis of 1,000 replicas was perfomed with the programs SEQBOOT and CONSENSE in the PHYLIP package.

\section{Results}

There was no significant difference in age and sex distribution between the patients from Sweden compared with those from Denmark (Table 1). Anti-HEV IgM and IgG was found in 85 patients, $57(67 \%)$ of those were males. There was also a predominance of males, 109/163 (67\%), among patients in whom only anti-HEV IgG without detectable IgM was found (Table 1). The mean age of the patients with anti-HEV IgM was 31.5 years, while those with only detectable anti-HEV IgG were older with a mean age of 43.6 years.

HEV RNA could be detected in serum from 65 of 141 tested anti-HEV positive patients (Table 2 ). The PCR in the ORF1 region was more sensitive and could amplify 63 of the strains, while 51 of the strains were amplified in the ORF2 region. HEV strains could be amplified in $68 \%$ of the sera from patients with IgM anti-HEV, as well as in $18 \%$ of sera from patients with detectable anti-HEV IgG only (Table 2).

The time of onset of disease in relation to the time of sample collection was known for 84 patients (Table 3). All six patients sampled 2-3 weeks after onset had detectable HEV RNA in serum when ORF 1 was amplified, while only three of these patients had detectable HEV RNA when ORF2 was amplified. In two patients HEV RNA was detected as long as five weeks after onset of illness.

The countries of infection, known for 126 (51\%) of the patients, were mainly in Asia with India, Pakistan and Bangladesh as dominating countries (Table 4). Twenty-nine patients (23\%) were infected in Europe, while the rest were infected in the Middle East, Africa or South America (Table 4). Six of the patients infected in Europe were injecting drug users (IDUs) and one case in Sweden was a contact of an HEV-infected relative from Pakistan [22].

The PCR amplified regions could be sequenced for 63 of the 65 PCR amplified isolates and 56 patients were found infected with genotype 1 , while seven were infected with genotype 3 (Table 4). Those with genotype 1 had all been infected in Asia and Africa, apart from the Swedish contact of a case from Pakistan, while all those with genotype 3 were infected in Europe.

There was a predominance of males in both groups, with five males among the seven patients infected by genotype 3 and 43 males among the 56 patients infected by genotype 1 . The patients infected by genotype 3 were older than those with genotype 1 . The mean age of patients infected with genotype 3 was 55.3 years, while the mean age of those with genotype 1 was 30 years $(p<0.001 ;$ unpaired t-test)

HEV RNA could be detected in six faecal samples from six out of 10 piglets tested (in six out of 10 Swedish breeding herds) and in eight samples from piglets originating from seven Danish breeding herds. All piglets were found infected with genotype 3 .
In the phylogenetic analysis all isolates could be allocated to either genotype 1 or 3 (Figure 1). It was also found that genotype 3 could be subdivided into two major clades, here tentatively designated 3-I and 3-II (Figures 1 and 2b). Subtypes 3a, c, and d clustered in clade $3-\mathrm{I}$, while strains of subtype $3 \mathrm{e}, \mathrm{g}$, and $\mathrm{f}$ were found in clade 3 -II (Figures 1 and $2 b$ ). This sequenced region of ORF2 was not available in GenBank for subtypes 3h and 3j. The 371 nucleotides of the genomic region coding for the methyltransferase was available for these subtypes and from three genotype $3 \mathrm{f}$ strains and was compared with the corresponding region of the genotype 3 strain from a Swedish pig (accession number EU360977). The nucleotide sequence of the Swedish pig strain diverged by $81-84 \%$ from subtype $3 \mathrm{~h}$ and $\mathrm{j}$ in this region, whereas it was $88-89 \%$ similar to subtype $3 \mathrm{f}$. Sequences of the same subtypes were similar in 88 $90 \%$ to each other and in $84-86 \%$ to the sequences of the other subtypes. Based on this comparison, the Swedish strains found in clade 3-II may belong to subtype $3 \mathrm{f}$.

Even if most genotype 1 sequences available in GenBank originate from India and Nepal, there was a geographical clustering with these strains and $1 \mathrm{a}, 1 \mathrm{~b}$ and $1 \mathrm{c}$ strains from China, Japan and Kyrgyzstan forming one cluster, while another cluster was formed by $1 \mathrm{~d}$ and $1 \mathrm{e}$ strains from Africa (Figure 2a). In our study, the majority of patients infected on the Indian subcontinent were infected by $1 a$. The sequences from isolates from India and Pakistan were similar to strains available in GenBank from these countries and from Nepal, while those from patients infected in Bangladesh were found on a separate branch. However, one strain from a patient infected with $1 a$ in Tanzania was more similar to strains from India than to strains from Africa, and was thus an exception.

The strains found in clade 3-I were from Asia, mainly Japan, South Korea and China, and the US. Two strains in our study were found in this clade, one was from a Swedish pig herd the other was from a woman infected in Serbia/Montenegro and was similar to a Japanese strain (AB094212). All other genotype 3 isolates in this study were found in clade 3 -II and clustered according to geographical origin (Figure 2b). There were two major subclusters within 3-II one was formed by $3 f$ strains from Europe the other by subtype 3 e and $3 g$ strains from Japan, Mongolia and Kyrgyzstan. There was geographical clustering also within the clade formed by European isolates. One branch was formed by strains from Spain and France, one with strains from the Netherlands and France and one with Swedish and Danish strains intermixed with three strains from Spain (Figure 2b). The isolates from one Swede and one Dane infected in Spain were similar to strains from Spanish pigs. The strains from individuals infected in Sweden or Denmark were all similar to strains from Swedish and Danish pigs (Figure 2b). Pig strains from two Swedish breeding herds were found similar to Japanese and Mongolian strains within clade 3-II.

\section{Discussion}

Hepatitis $E$ is not considered a major public health problem in non-endemic countries. This study confirms that most cases of hepatitis $\mathrm{E}$ in Scandinavia are imported from Asia. However, several cases have been infected in Europe, which is generally regarded as a non-endemic region. There have been rather few reported cases of autochthonous hepatitis $\mathrm{E}$ in European countries to date $[11,19,21]$, although several reports have shown a seroprevalence ranging from 5 to 33\% in the adult population in Europe, Japan and the US [11,15-18]. This indicates that hepatitis $E$ is not uncommon in these countries, although most infections are subclinical or inapparent. 
F I G U R E I

Phylogenetic tree based on 279 nucleotides of the capsid region of ORF 2 in 638 hepatitis E virus (HEV) strains

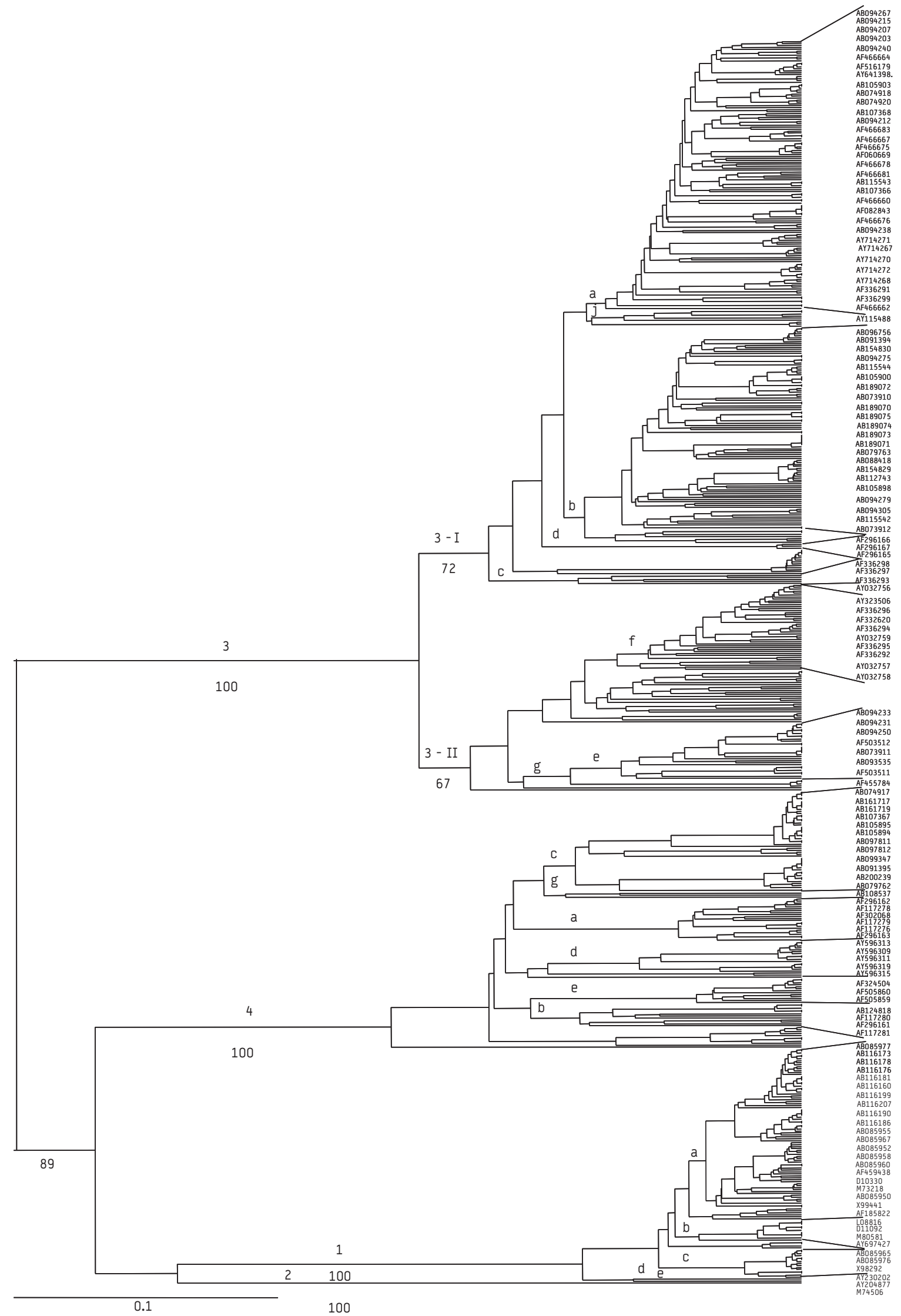

The branches with strains of known subtypes are marked with the subtype designation. The accession numbers of the strains with known subtypes according to Lu et al. 2006 [2] are given at the nodes with lines separating strains belonging to different subtypes. The figures at the internal nodes are boot strap values of 1,000 replicas. 
F I GU R E 2 A

Branch formed by genotype 1 strains of the phylogenetic tree shown in Figure 1

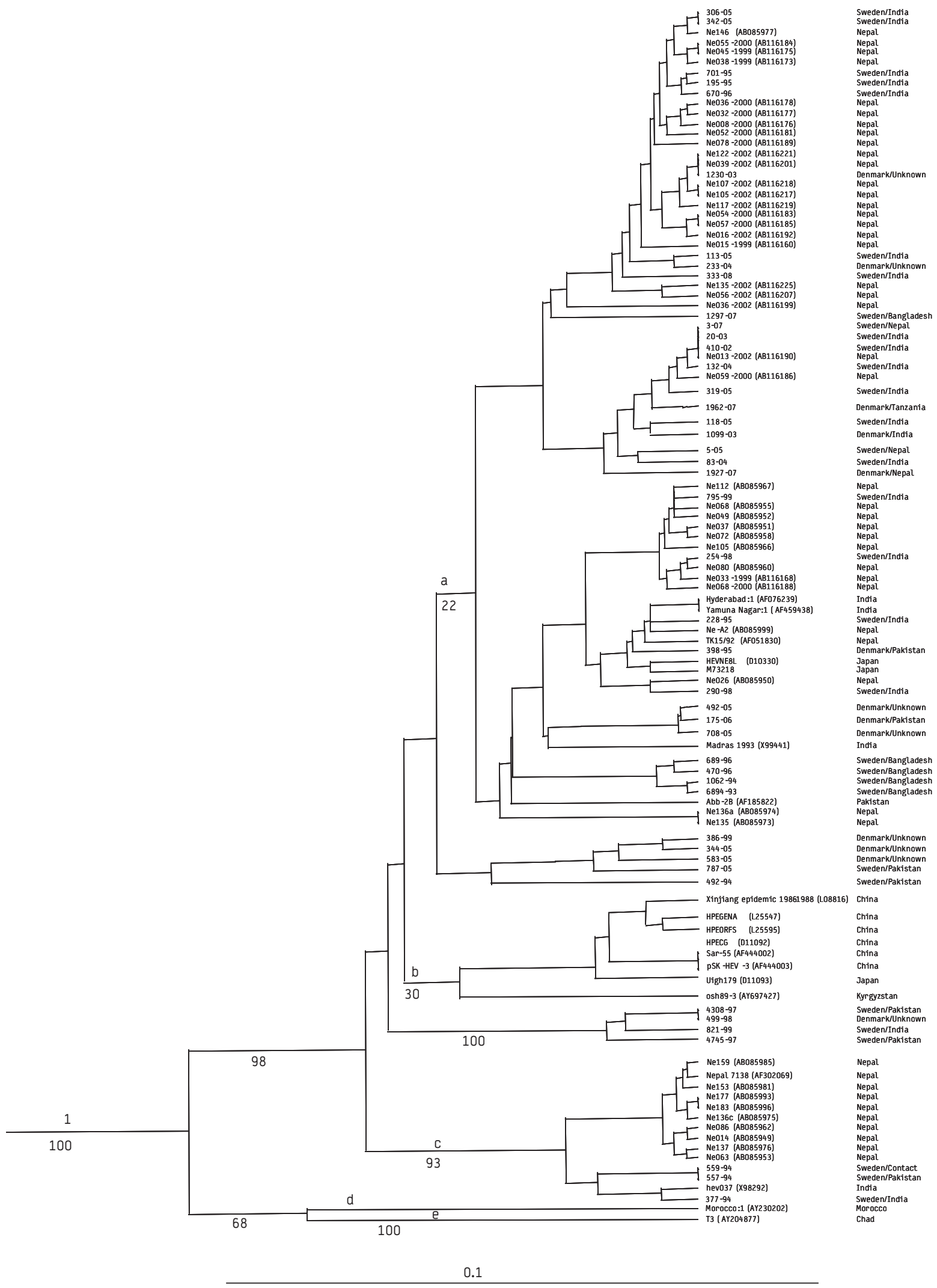

The strains described in this study are shown in bold. The figures at the internal nodes are boot strap values of 1,000 replicas. 
F I G U R E 2 B

Branch formed by the genotype 3 strains forming branch 3-II shown in Figure 1

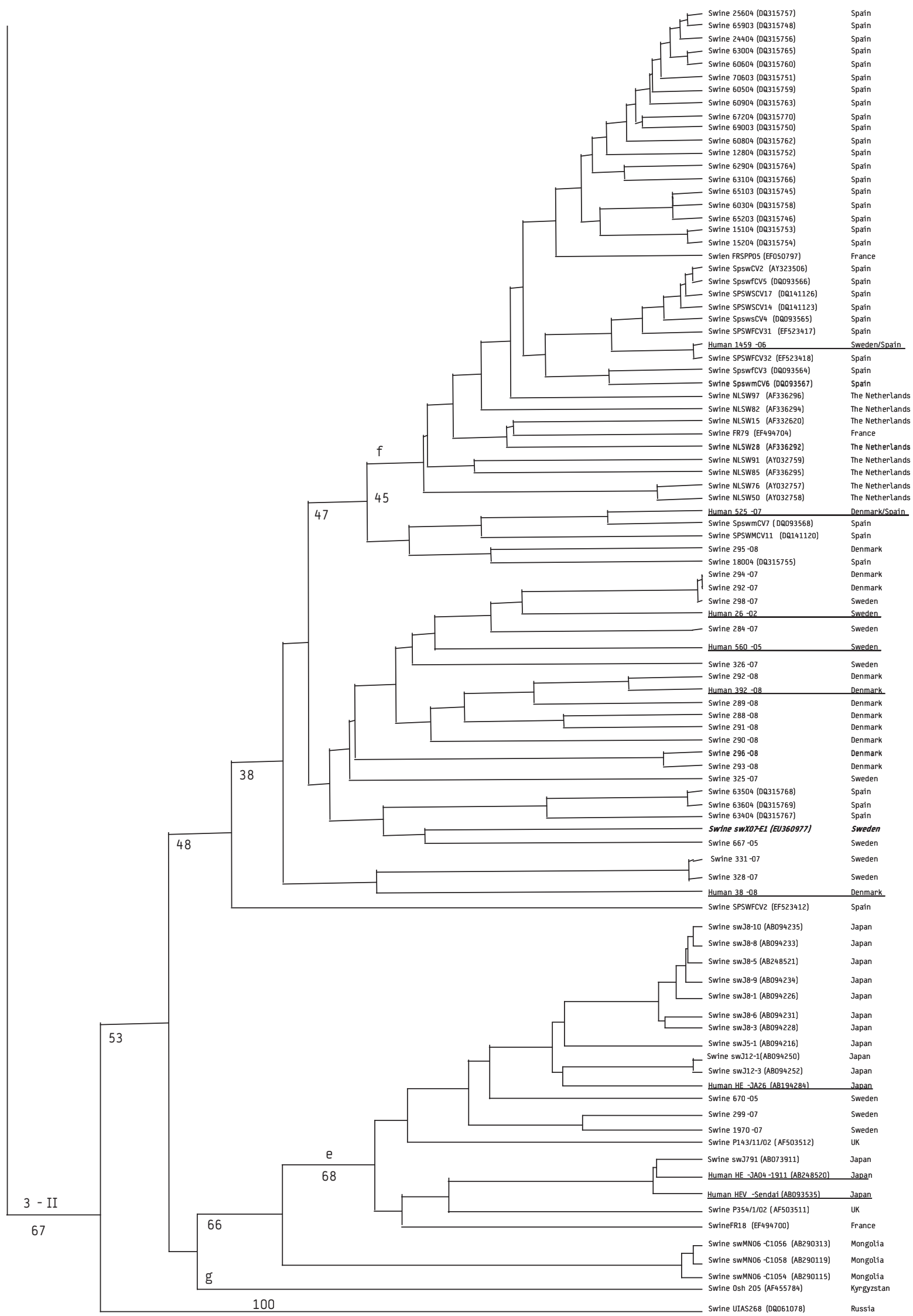

The human genotype 3 strains are underlined; those described in this study are in addition shown in bold. The HEV sequences from domestic pigs described in this study are shown in bold italic. The figures at the internal nodes are boot strap values of 1,000 replicas. 
In our study HEV RNA was detected in $67 \%$ of sera sampled within three weeks after onset of illness from patients with this information known. This is in accordance with an HEV RNA detection rate of $56-59 \%$ in sera sampled 15 to 20 days after onset in Chinese patients with hepatitis E [23]. However, in our study HEV RNA was also detected in $18 \%$ of sera from patients with anti-HEV IgG only, which is an unexpectedly high frequency and has not been described earlier, since the presence of IgG in the absence of detectable IgM is considered a marker of past infection. AntiHEV IgG may persist for several years after infection, but whether lifelong immunity is conferred remains uncertain [24]. There is only one serotype of HEV, but it is not known if reinfections induce IgG response only or if also the IgM levels become elevated. It is also not known if there is a viremic phase during a reinfection when the level of IgG is low and the immune response has been elicited towards another HEV genotype. Since most of the patients in this study were from Scandinavia and it is known that there is a rather high seroprevalence against HEV in Sweden and Denmark [16-18] it is possible that individuals with low level antibodies towards genotype 3 when infected with genotype 1 developed disease and viraemia with anti-HEV IgG elevation only.

In this study the only case infected by genotype 1 in Europe was epidemiologically linked to a case from Pakistan. All other patients infected in Europe were infected with genotype 3 strains. These individuals were mainly males and were 20-25 years older than the cases infected by genotype 1 . This is in accordance with previous recent reports from the UK, France and Germany showing that genotype 3 is the autochthonous genotype of HEV, which gives disease mainly in males over the age of $50[15,25]$.

Since autochthonous hepatitis $\mathrm{E}$ in humans in Europe has been caused by strains with $99-100 \%$ identity to European swine HEV [26], the suspected route of infection is through direct contact with pigs or other infected mammals or by foodborne transmission. Foodborne transmission was described in Japan in patients infected after consumption of undercooked pig liver or meat from wild boar or deer [27-29]. This route of infection may occur also in Europe since HEV has been detected in commercial pig liver sold in groceries and there is a high HEV seroprevalence in many pig herds $[30,31]$. Phylogenetic analysis of the genotype 3 strains revealed that most Asian and American strains belong to one major clade and that the European strains belong to another clade. There were also geographical clades of the genotype 3 strains, and strains from patients infected in Sweden and Denmark were similar to strains from Swedish and Danish piglets, while patients infected in Spain had genotype 3 strains similar to those of Spanish pigs. This pattern has previously not been described and enables a possible identification of the country of origin of the strain infecting the patient. This in turn may help to trace the source of infection and to identify a possible food item from that country.

Antibodies to HEV have been shown to be prevalent among blood donors and apart from the faecal-oral and foodborne route HEV may be transmitted also through blood or blood products as has been reported from Japan, Saudi Arabia, France, and the UK [32-34]. HEV has also been reported to be transmitted by organ transplantations [35]. Some organ-recipients have developed chronic hepatitis E infection [10]. In our study the viraemia lasted for a relatively long period in most patients. Thus, transmission of HEV by blood or blood products may theoretically also occur in Sweden. Bloodborne transmission may also occur through injecting drug use. In our study six of the patients were IDUs among those with HEV IgG but no detectable HEV IgM or RNA. More than $60 \%$ of Swedish IDUs have anti-HEV [17], which further supports the conclusion that hepatitis $\mathrm{E}$ may be transmitted parenterally in this cohort of individuals. The high seroprevalence indicates that most probably IDUs are frequently reinfected with HEV. The IDUs in our study were investigated for HEV infection due to elevated transaminases. However, genotype 3 reinfections have been shown not to induce elevation of liver enzymes or detectable HEV IgM among patients on hemodialysis in Japan [36], but HEV RNA was not looked for in these patients. It is thus not known if reinfections with genotype 3 cause viraemia. Lack of HEV RNA in the sera from the anti-HEV IgG positive IDUs may either indicate that reinfection with genotype 3 does not give rise to viraemia, or that a continuous low-level exposure to HEV keeps the immune status at a level preventing reinfection with $\mathrm{HEV}$, or that there is a long lasting immunity with detectable HEV IgG.

Hepatitis $E$ in developed countries has a natural history that differs from classical hepatitis $E$ in endemic areas. In the study presented here we have shown that HEV genotype 3 strains are indigenous in Sweden and Denmark, with high similarity between strains infecting humans and pigs. Prospective studies are needed to define the incidence of autochthonous infections in Scandinavia. It is also important to determine whether and how the spread occurs from pigs to humans and if there are other animal sources for zoonotic transmission of HEV, since genotype 3 appears to be a primarily animal virus that crosses the species barrier. In conclusion, hepatitis $\mathrm{E}$ should thus be considered in the diagnosis of patients with acute hepatitis, regardless of travel history.

\section{Aknowledgements}

This work was supported by the European Commission DG Research Quality of Life Program, 6th Framework (EVENT, SP22-CT-2004-502571) and by the European Commission DG Research Biotechnology, Agriculture and Food Research programme, 6th Framework Programme (Pathogen Combat, Food-CT-2005-007081), the European Commission DG Research Network for the Prevention and Control of Zoonoses, (MedVetNet, F00D-CT-2004-506122) and the Sandberg Foundation, Sweden.

\section{References}

1. Balayan MS, Andjaparidze AG, Savinskaya SS, Ketiladze ES, Braginsky DM, Savinov AP, et. al. Evidence for a virus in non-A, non-B hepatitis transmitted via the fecal-oral route. Intervirology. 1983;20(1):23-31.

2. Lu L, Li C, Hagedorn CH. Phylogenetic analysis of global hepatitis E virus sequences: genetic diversity, subtypes and zoonosis. Rev Med Virol. 2006;16(1):5-36.

3. Shukla P, Chauhan UK, Naik S, Anderson D, Aggarwal R. Hepatitis E virus infection among animals in northern India: an unlikely source of human disease. J Viral Hepat. 2007;14(5):310-7.

4. Schlauder GG, Dawson GJ, Erker JC, Kwo PY, Knigge MF, Smalley DL, et al. The sequence and phylogenetic analysis of a novel hepatitis $E$ virus isolated from a patient with acute hepatitis reported in the United States. J Gen Virol. 1998;79(Pt3):447-56.

5. Takahashi K, Iwata K, Watanabe N, Hatahara T, Ohta Y, Baba K, et al. Full-genome nucleotide sequence of a hepatitis $E$ virus strain that may be indigenous to Japan. Virology. 2001;287(1):9-12

6. Mansuy JM, Peron JM, Abravanel F, Poirson H, Dubois M, Miedouge M, et al. Hepatitis $\mathrm{E}$ in the south west of France in individuals who have never visited an endemic area. J Med Virol. 2004;74(3):419-24.

7. Ijaz S, Arnold E, Banks M, Bendall RP, Cramp ME, Cunningham R, et al. Nontravel-associated hepatitis $E$ in England and Wales: demographic, clinical, and molecular epidemiological characteristics. J Infect Dis. 2005;192(7):1166-72.

8. Hamid SS, Atiq M, Shehzad F, Yasmeen A, Nissa T, Salam A, et al. Hepatitis E virus superinfection in patients with chronic liver disease. Hepatology. 2002;36(2):474-8. 
9. Khuroo MS, Kamili S. Aetiology, clinical course and outcome of sporadic acute viral hepatitis in pregnancy. J Viral Hepat. 2003;10(1):61-9.

10. Haagsma EB, van den Berg AP, Porte RJ, Benne CA, Vennema H, Reimerink JH, et al. Chronic hepatitis E virus infection in liver transplant recipients. Liver Transpl. 2008;14(4):547-53.

11. Dalton HR, Thurairajah PH, Fellows HJ, Hussaini HS, Mitchell J, Bendall R, et al. Autochthonous hepatitis E in southwest England. J Viral Hepat. 2007;14(5):3049.

12. Widdowson MA, Jaspers WJ, van der Poel WH, Verschoor F, de Roda Husman AM, Winter HL, et al. Cluster of cases of acute hepatitis associated with hepatitis E virus infection acquired in the Netherlands. Clin Infect Dis. 2003;36(1):29-33

13. Dalton HR, Fellows HJ, Gane EJ, Wong P, Gerred S, Schroeder B, et al. Hepatitis E in New Zealand. J Gastroenterol Hepatol. 2007;22(8):1236-40.

14. Mizuo H, Suzuki K, Takikawa Y, Sugai Y, Tokita H, Akahane Y, et al. Polyphyletic strains of hepatitis $E$ virus are responsible for sporadic cases of acute hepatitis in Japan. J Clin Microbiol. 2002;40(9):3209-18.

15. Mansuy JM, Abravanel F, Miedouge M, Mengelle C, Merviel C, Dubois M, et al. Acute hepatitis $E$ in south-west France over a 5-year period. J Clin Virol. 2009;44(1):74-7.

16. Christensen PB, Engle RE, Hjort C, Homburg KM, Vach W, Georgsen J, et al. Time trend of the prevalence of hepatitis $E$ antibodies among farmers and blood donors: a potential zoonosis in Denmark. Clin Infect Dis. 2008;47(8):1026-31.

17. Sylvan SP. The high rate of antibodies to hepatitis $E$ virus in young, intravenous drug-abusers with acute hepatitis B-virus infection in a Swedish community: a study of hepatitis markers in individuals with intravenously or sexually acquired hepatitis B-virus infection. Scand J Infect Dis. 1998;30(4):429-30.

18. Olsen B, Axelsson-Olsson D, Thelin A, Weiland 0 . Unexpected high prevalence of IgG-antibodies to hepatitis E virus in Swedish pig farmers and controls. Scand J Infect Dis. 2006;38(1):55-8.

19. Zhai L, Dai X, Meng J. Hepatitis E virus genotyping based on full-length genome and partial genomic regions. Virus Res. 2006;120(1-2):57-69.

20. Meng XJ, Purcell RH, Halbur PG, Lehman JR, Webb DM, Tsareva TS, et al. A novel virus in swine is closely related to the human hepatitis E virus. Proc Natl Acad Sci U S A. 1997;94(18):9860-5.

21. Felsenstein J. PHYLIP: Phylogeni inference package; version 3.52c. Seattle (WA, US): University of Washington; 1993.

22. Söderström A, Hammas B, Magnius L, Norkrans G. [A secondary case of hepatitis E. Since 1990 only one of the 17 imported cases was transmitted] Lakartidningen. 1995;92(50):4807-8.

23. Zhao ZY, Ruan B, Shao H, Chen ZJ, Liu SL. Detection of hepatitis E virus RNA in sera of patients with hepatitis $\mathrm{E}$ by polymerase chain reaction. Hepatobiliary Pancreat Dis Int. 2007;6(1):38-42.

24. Aggarwal R, Krawczynski K. Hepatitis E: an overview and recent advances in clinical and laboratory research. J Gastroenterol Hepatol. 2000;15(1):9-20.

25. Dalton HR, Stableforth W, Thurairajah P, Hazeldine S, Remnarace R, Usama W, et al. Autochthonous hepatitis E in Southwest England: natural history, complications and seasonal variation, and hepatitis E virus IgG seroprevalence in blood donors, the elderly and patients with chronic liver disease. Eur J Gastroenterol Hepatol. 2008; 20(8):784-90.

26. Herremans M, Vennema H, Bakker J, van der Veer B, Duizer E, Benne CA, et al. Swine-like hepatitis $E$ viruses are a cause of unexplained hepatitis in the Netherlands. J Viral Hepat. 2007;14(2):140-6.

27. Yazaki Y, Mizuo H, Takahashi M, Nishizawa T, Sasaki N, Gotanda Y, et al. Sporadic acute or fulminant hepatitis $\mathrm{E}$ in Hokkaido, Japan, may be food-borne, as suggested by the presence of hepatitis $E$ virus in pig liver as food. J Gen Virol. 2003;84(Pt9):2351-7.

28. Michitaka K, Takahashi K, Furukawa S, Inoue G, Hiasa Y, Horiike N, et al Prevalence of hepatitis $E$ virus among wild boar in the Ehime area of western Japan. Hepatol Res. 2007;37(3):214-20.

29. Matsuura Y, Suzuki M, Yoshimatsu K, Arikawa J, Takashima I, Yokoyama M, et al. Prevalence of antibody to hepatitis E virus among wild sika deer, Cervus nippon, in Japan. Arch Virol. 2007;152(7):1375-81.

30. Bouwknegt M, Lodder-Verschoor F, van der Poel WH, Rutjes SA, de Roda Husman AM. Hepatitis E virus RNA in commercial porcine livers in The Netherlands. J Food Prot. 2007;70(12):2889-95.

31. Meng XJ, Dea S, Engle RE, Friendship R, Lyoo YS, Sirinarumitr T, et al. Prevalence of antibodies to the hepatitis E virus in pigs from countries where hepatitis $\mathrm{E}$ is common or is rare in the human population. J Med Virol. 1999;59(3):297-302.

32. Matsubayashi K, Kang JH, Sakata H, Takahashi K, Shindo M, Kato M, et al. A case of transfusion-transmitted hepatitis $E$ caused by blood from a donor infected with hepatitis E virus via zoonotic food-borne route. Transfusion. 2008;48(7):1368-75

33. Boxall E, Herborn A, Kochethu G, Pratt G, Adams D, Ijaz S, et al. Transfusiontransmitted hepatitis $E$ in a 'nonhyperendemic' country. Transfus Med. 2006;16(2):79-83.
34. Colson P, Coze C, Gallian P, Henry M, De Micco P, Tamalet C. Transfusionassociated hepatitis E, France. Emerg Infect Dis. 2007;13(4):648-9.

35. Kamar N, Mansuy JM, Esposito L, Legrand-Abravanel F, Peron JM, Durand D, et al Acute hepatitis and renal function impairment related to infection by hepatitis E virus in a renal allograft recipient. Am J Kidney Dis. 2005;45(1):193-6.

36. Mitsui T, Tsukamoto Y, Yamazaki C, Masuko K, Tsuda F, Takahashi M, et al. Prevalence of hepatitis $\mathrm{E}$ virus infection among hemodialysis patients in Japan: evidence for infection with a genotype $3 \mathrm{HEV}$ by blood transfusion. $\mathrm{J}$ Med Virol. 2004;74(4):563-72.

This article was published on 14 May 2009.

Citation style for this article: Norder H, Sundqvist L, Magnusson L, Østergaard Breum S, Löfdahl M, Larsen LE, Hjulsager CK, Magnius L, Böttiger BE, Widén F. Endemic hepatitis E in two Nordic countries. Euro Surveill. 2009;14(19):pij=19211. Available online: http:// www.eurosurveillance.org/ViewArticle.aspx?ArticleId=19211 